\title{
The Relation Between the Growth in the Number of Female Single Parent Families and the Number of Women Imprisonment in Brazil
}

\author{
Deborah Bandeira de Deus e Mello \\ Faculdade de Direito, Universidade Nova de Lisboa \\ Eglantina Albuquerque de Oliveira Souza e Silva \\ Faculdade de Direito, Universidade de Lisboa
}

\begin{abstract}
This article proposes to analyze the current conjecture of Brazil in which it was observed by the studies a relevant growth in female single-parent families combined with the observation that in face of the situation in these families, women are driven to crime and consequently to prison. Female single-parent families with children are more "vulnerable" in economic terms, in food supplies and in the caring provided to the children. In this way, families that are headed by these women occur in these circumstances, often allied to their will and consequently the entering of these women in world of crime, so their imprisonment interferes in the whole family. Therefore, we aim with this article to establish a relation between this increase in the number of families headed by women and the increase of women deprived of liberty. The theoretical and methodological support that conducted this research is anchored in the socioeconomic perspective, starting from an investigation of incarcerated women, the family situation and the type of crime committed, since most women do not commit violent crimes. Within a qualitative approach, being the technical procedure adopted of a descriptive-analytical character, carried out through analysis of bibliographic content and data. In this way, we will discuss the socioeconomic reality of incarcerated women, the family situation and how this situation affects the committing of crime and, consequently, incarceration. There would be a concrete relationship between two data, an increase in the number of female single-parent families and because of that, an increase in the number of incarcerated women? It appears that women in situation of vulnerability are the majority among prisoners and considering the circumstances they are arrested it stays very clear the gender hierarchy in social and prison environment which they are subjected. In advance, we noticed that there is a need to create more public policies that promote social justice and greater support for families where women are the main supporters in order to minimize their possible entry into the world of crime.
\end{abstract}

Keywords: Female Single Parenting, Female Imprisonment, Public Policy, Human Rights.

DOI: $10.7176 /$ RHSS/11-11-07

Publication date:June $30^{\text {th }} 2021$

\section{Introduction}

We begin this article by presenting a terminological alternative to the term "single mother", since this commonly used expression carries a strong remnant of a $20^{\text {th }}$-century sexist and patriarchal society in which married women had their civil, sexual and reproductive rights limited, and mostly submitted to the husband's will. To be married was a primordial factor in order for women to become mothers (Borges, 2020). According to Silvio de Salvo Venosa (2018), the term "single mother" was for a long time considered under the lens of a social control view in patriarchal society, in which maternity presented itself as the element of submission of women in relation to men. By altering the way these women are referred to, we intend to extinguish the prejudice against genitors who do not possess any relations with the father of their offspring. Therefore, we will use the expression 'solo mother', women who are the head of their single parent families.

There are several possibilities of single-parent family formation: women who are mothers by means of unilateral adoption, voluntary maternity, medically assisted reproduction, or even due to abandonment or father's omission - the latter two situations being extremely common in the Brazilian reality. The National Household Sample Survey (PNAD, in Portuguese) conducted by the Brazilian Institute of Geography and Statistics (IBGE) in 2018 observed that seven years earlier, this variable in the data collection was of 954 thousand women in the condition of household leadership, and in the year 2018 it rose to 1,4 million women. A relevant increase allusive to the families in which the women holds the responsibility and they are qualified by the mother-child(ren) bond, without the presence of a conjugal relationship.

Additionally, to further investigate the theme of our article, we observe that there has been an expressive rise in the number of incarcerated women in recent years. Thus, considering that female single-parent families are more prone to a situation of vulnerability, we enquire whether it is possible to associate the growth of female single-parent families with the number of incarcerated women. 


\section{Female emancipation and gender inequality}

Over recent years a relative female emancipation has been achieved, as well as a development in the concept of family, diminishing, at least in part, the necessity of maintaining a conjugal relationship in order to raise a family. Legislative changes were determinant to such shifts beyond conjugal relationship, for instance: the Married Woman's Stature (Estatuto da Mulher Casada - Lei $\mathrm{n}^{\mathrm{o}}$ 4.121/1962), the Divorce Constitutional Amendment (Emenda constitucional $n^{\circ}$ 9, de 28 de junho de 1977 ) and the Divorce Law (Lei do Divórcio -Lei 6.515/1977), the Federal Constitution of 1988 (Constituição Federal de 1988 ), the Child and Adolescent Statute (Estatuto da Criança e do Adolescente de 1990) and the Brazilian Civil Code of 2002 (Código Civil Brasileiro de 2002). It is important to highlight the Federal Constitution recognition of the single-parent familied, which is a landmark to the formation of the family by either parent and their descendants, since it removes the need for a conjugal relationship to its existence, establishing a new form of family constitution. (Borges, 2020).

Through these changes, modern society promoted distinct views on the role of women in society. At the end of the $20^{\text {th }}$ century, the freedom suggested by Feminism contributed heavily to the interruption of determinism and discrimination, which led to a conflict about the egalitarian behavior in parental roles when it came to raising children.

Thus, maternity no longer resulted from a conjugality per se, but rather from the parenthood, the will to become a mother, therefore, it was not the spouse who turned them into mothers, their kid(s) did (Bassete, 2018). Solo mothers are the only responsible for their children and many times they must conciliate such role with their professional career. These women face moral criticism imposed by the society's family ideal, which intimidates them into following the marriage tradition, forcing the man into a primordial role so that the woman may exert her maternity.

\section{The solo-mother overload}

Solo mothers experience an enormous physical and mental overload, since they need to manage activities such as playing, feeding, cooking, bathing, changing diapers, taking their kids to the doctor, doing laundry, tiding up the house, taking their kids to school, assisting them with school assignments and conciliating all of it with their professional career. According to "Primeiríssima Infância ", in cases analyzes in a survey realized in 2017, it was found that $89 \%$ of the children up to three years old are taken care of by their mothers (Martins, 2017).

However, the care work imputed to women regarding the raising of their children, the domestic chores and their weekly workload is not viewed by society as work per se, since it is inserted in a patriarchal society. The raising, educating and socializing of their children, that is, the care work, is strictly connected to the "capacity of being a good mother" to society. Going through social roles, entering once more in discriminatory implications, so that the woman can neither perform certain behaviors nor have particular skills exclusively due to the fact of being a mother.

The maternal overload is, unfortunately, still normalized by society, as are other issues namely the father's omission in relation to the care work and the father abandonment, which reflects the gender inequality regarding this matter. This may lead to the conclusion the woman who is a solo mother and does not receive any material aid from the genitor might be put in a situation of greater vulnerability in relation to the other families since, as Angela Davis (2016, p.230) observes "housework does not generate profit, domestic labour was naturally defined as an inferior form of work as compared to capitalist wage labour".

\section{Inequality in the job market and the subsistence of the solo mother}

Besides the solo mother overload, it is important to highlight that the inequality is also in the job market and, consequently, the female single-parent family faces a greater livelihood difficulty. The National Household Sample Survey (PNDA) which was realized in 2018 and aimed to investigate the female overload in the care work noticed that women who work outside the home dedicate circa eighteen hours per week to domestic chores and caring of the children, while inactive or unemployed men dedicate twelve hours per week to the same activities. To work like they do not have children, and raise children like they do not work outside the home (Lizaukas, 2019).

Even though discrimination against gender is forbidden, as provided for in the Federal Constituion of 1988 (Constituição Federal de 1988 ) and reiterated in some devices of the Consolidation of Labour Laws (Consolidação das Leis do Trabalho de 1943), women are also discriminated when it comes to the gender pay gap and opportunities of growth in the labour force.

According to the data published by IBGE (2017), the poverty rate per family is higher in the ones that are composed by women without a spouse and with children. Although wage difference related to gender is unlawful, researches show that women earn less than men in all areas and positions, making it clear that the gap can reach up to the level of fifty-three per cent, this fact added to the knowledge that women are still the minority in management positions.

One needs to analyze the matter of the livelihood itself, the insertion in the job market and the equality of 
opportunities regarding gender, considering that according to data from the National Household Sample Survey (PNDA), black women, on average, earn $46 \%$ (forty-six per cent) of the white men remuneration. They are the ones with the lowest income among higher-education workers (Belloni, 2017).

Even when seeking to be inserted in the job market, women with children are harmed merely by the fact that they are mothers. A study by the American Journal of Sociology, showed that in a hiring situation in which the candidates are equal in every aspect, if there is the subtlest indication that one of them is a mother, the probability of the mother being chosen is reduced in 37\% (thirty-seven per cent) (Goldstein, 2019). In this sense, it is relevant to point out the "romanticized view" of the mother entrepreneurship, where the high unemployment rate push these women into putting themselves in the job market as entrepreneurs, since they need the reinsertion in it after maternity - according to a research by Global Entrepreneurship Monitor (GEM, 2016) in partnership with SEBRAE and IBPQ (AGÊNCIA SEBRAE DE NOTÍCIAS BRASÍLIA, 2018).

\section{The relation between single-parent families and incarcerated women}

Is it possible to establish a relation between the growing number of female single-parent families and of incarcerated women? That is our enquiry. And primarily, in face of the facts, we though so. We have observed that female single-parent families are generally in situation of vulnerability. Resources are not provided by the genitors and these mothers normally recur to a social support or a kinship network to obtain the income necessary to the livelihood of their family, since she is the one charged with the responsibility for the development and maintenance of the family (Silva, 2015).

Thus, there is only one adult responsible for the household in these families, and they are more likely to be unemployed or engaged in an informal job, usually earning the lowest wages. For all of these reasons, they end up seeking financial alternatives, be ir through prostitution or drug dealing "since, the woman neither having the qualification for the job market nor the conditions to maintain the household, drug dealing presents itself as an accessible alternative to her, once she can carry this from her own home" (Silva, 2015, p.141).

\section{The profile of the incarcerated woman}

At first, to observe the possible relation intended with this work, it is important to clarify an initial matter about the profile of incarcerated women. According to INFOPEN (2019), 78\% of imprisoned women have children and $68 \%$ of them are single, widowed, separated or divorced, which lead us to understand that a large proportion of these women may not have the assistance of the genitor to raise and/or support their children.

Added to the previous fact, we have observed that the schooling profile of the incarcerated woman is a factor that could contribute to this understanding, since we know only $18,09 \%$ of incarcerated women have graduated high school and only 1,5 hold a college degree (INFOPEN, 2019), which illustrate a lack of formal qualification that could help them in the search for employment.

The types of crimes committed also prove to be an important factor. We have observed that crimes involving drug dealing, theft or robbery make up to a total of $80,68 \%$ of the crimes perpetrated and "one observes that drug dealing is the $46^{\text {th }}$ main responsible for most of the imprisonments, adding up to a total of $59,9 \%$ of the cases (INFOPEN, 2019, pp.45-46). That is, three out of five women who find themselves in the prison system due to drug dealing charges.

Another factor we consider important to analyze is the average jail time incarcerated women are submitted to in Brazil. INFOPEN (2019) data points out that $61,39 \%$ are convicted with the maximum penalty of 8 years and this amount of time may reflect that women's participation in drug dealing is minimal, that they might play a role as small dealer for livelihood reasons or simply a "mule" (Fregapani as cited inVinhal, 2018). Therefore, we can understand that the profile of the incarcerated women illustrates the possible vulnerability they might have, particularly when speaking of solo mothers.

\section{Crime as an income increase}

The overall profile of the incarcerated woman being analyzed, it is also important to our study to analyze, albeit in a simple manner, the causes for these women to enter the criminal world. We point out that this article does not aim to present a deep analysis of such a theme here since it is not fit for the context of this work. Rather, we aim to make a general observation of the fact.

According to Davim e Lima (2016) the abandonment of the provider may be a influencing factor. Women who suffer father's abandonment when they were kids might be more prone to crime, and mainly, women who experienced a financial abandonment, since when it comes to women, such neglect can limit their social development as well as force them to become their own providers earlier, having to drop out of school to work and because of that, they tend to move from underemployment to underemployment. This fact corroborates the previously presented data that most of these women do not have a complete formal education

Thus, as they reach adult life, the tendency to repeat the story is almost a rule. The daughter becomes a mother and the cycle begins again. In this stage of their lives, they face a second abandonment, the husband's. 
After the separation, the woman becomes the head of the household and solely responsible for supporting the children. Overwhelmed, some appeal to illegal means as a way of earning an extra money to help with the family budget. (Davim e Lima, 2016, pp 140-141)

A study by Josineide Aquino da Silva Amaral (2019) corroborates with this understanding when it reports that $74,1 \%$ of women say that their income was not enough to support the family, independent of the type of family. Besides, as seen in previous data, four-fifths of the incarcerated women are being charged with the crimes of drug dealing, theft or robbery and this confirms the idea by Queiroz (2015) that in general, the most common criminal offences are the ones that might complement the budget of these women, acting as a rental increase.

In other words, the search for an income practicing crimes such as drug dealing is one of the main factors for the woman's entry into the world of crime, since she is neither qualified to establish herself in the job market nor to support the family and household. Besides that, there is a neglect on the part of the government, a lack of a large social protection network, leaving the woman and her children vulnerable and exposed to drug traffic recruiters since they promise a guarantee of financial independence via crime (Silva, 2015).

\section{Final Considerations}

In recent years, there has been a considerable rise in the number of incarcerated women in Brazil. The factors that led to such a rise are countless, however, we consider there might be a relation between this growth and the rise of women who are the head of a single-parent family, since they are the only ones who have to provide for them.

To present our understanding it was necessary to consider, firstly, a general aspect of the Brazilian woman and mostly, the woman who is a mother and head of this single-parent family. The number of solo mothers, commonly known as solo mothers due to the patriarchal culture of our society, has increased immensely in the last few years. Many of these women do not receive any material aid from the genitors of their children and so, they need to support the livelihood of their children and household.

As presented, it is known that gender inequality surrounds our country, and such inequality tends to introduce the woman to a substantially more difficult world. The gender pay gap is evident as well as the difference of opportunities, these women tend to work in more informal jobs and they still need to take care of the children when they come home. The lack of qualification added to the lack of opportunity to obtain such a qualification are also factors that corroborate the tendency of a greater vulnerability of the woman, mainly the solo mother who is the head of a single-parent family, who attempts to seek in crime some form of survival strategy.

Thus, due to this greater vulnerability, these women are led to seek other means to support their household and their children, and it is then that the world of crime appears. The greater vulnerability of the woman who is the head of the family, the home's financial provider, makes her an easy target for the drug traffic recruiters. They see in crime a way of supplement the family budget, thus, practicing theft, robbery and drug dealing would appear as part of the family income and not only as a crime in itself.

Therefore, in face of such a vulnerability, one realizes the importance of the State when one considers that the problem of poverty and female single-parenthood may lead the woman to criminality and consequently, to imprisonment, since assistentialist public policies can be essential to the maintenance and support of these families.

\section{References}

AMARAL, J. (2019) DETERMINANTES DA ENTRADA DAS MULHERES NO TRÁFICO DE DROGAS: UM ESTUDO PARA O ACRE (BRASIL). Retrieved 15 dec, 2020 from http://tede.unioeste.br/bitstream/tede/4724/2/Josineide_Amaral_2019.pdf

AGÊNCIA SEBRAE DE NOTÍCIAS BRASÍLIA (2018) Por necessidade, mulheres começam a empreender após a maternidade. Brasília, 9 maio. Retrieved 08 dec, 2020 from https://revistapegn.globo.com/Mulheres-empreendedoras/noticia/2018/05/pornecessidade-mulherescomecam-empreender-apos-maternidade.html

BASSETTE, F.(2018). Brasileiras triplicam busca por congelamento de óvulos para adiar maternidade. BBC News. São Paulo, 21 set 2018. Retrieved 19 dec, 2020 from https://www.bbc.com/portuguese/geral45325932

BELLONI, L.(2017). Mulher negra graduada no Brasil recebe 43\% do salário de homem branco. Huffpost Brasil. São Paulo, 16 nov de 2017. Retrieved 11 dec, 2020 from https://www.huffpostbrasil.com/2017/11/16/mulher-negra-graduada-no-brasil-recebe-43-do-salario-dehomem-branco a 23279872/

BORGES, L. (2020) MÃE SOLTEIRA NÃO. MÃE SOLO! CONSIDERAÇÕES SOBRE MATERNIDADE, CONJUGALIDADE E SOBRECARGA FEMININA. Revista Direito e Sexualidade n. 1 (maio). Retrieved 
12 nov., 2020 from https://periodicos.ufba.br/index.php/revdirsex/article/view/36872/21118

Código Civil Brasileiro (2002) Lei n 10.406, de 10 de janeiro de 2002 Retrieved 19 dec, 2020 from http://www.planalto.gov.br/ccivil_03/leis/2002/110406compilada.htm

Consolidação das leis do Trabalho de 1943 Decreto-lei $n^{\circ}$ 5.452, de $1^{\circ}$ de maio de 1943 Retrieved 15 jan., 2021 from http://www.planalto.gov.br/ccivil_03/decreto-lei/del5452.htm

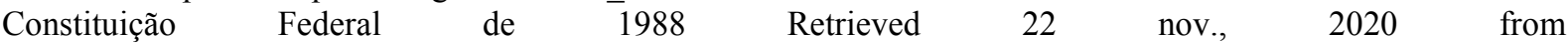
http://www.planalto.gov.br/ccivil_03/constituicao/constituicao.htm

DAVIM, B. K. G.; LIMA, C. S. (2017) CRIMINALIDADE FEMININA: DESESTABILIDADE FAMILIAR E AS VÁRIAS FACES DO ABANDONO. Revista Transgressões, v. 4, n. 2, p. 138-157, 8 abr.

DAVIS, A. (2016). Mulheres, Raça e Classe. trad. Heci Regina Candiani - $1^{\mathrm{a}}$ ed. - São Paulo, Boitempo.

Emenda constitucional $\mathrm{n}^{\mathrm{o}}$ 9, de 28 de junho de 1977 Retrieved 22 nov., 2020 from http://www.planalto.gov.br/ccivil_03/constituicao/emendas/emc_anterior1988/emc09-77.htm

Estatuto da Criança e do Adolescente de 1990 Retrieved 22 nov., 2020 from http://www.planalto.gov.br/ccivil 03/leis/18069.htm

Estatuto da Mulher Casada - Lei $\mathrm{n}^{\mathrm{o}} 4.121 / 1962 \quad$ (1962) Retrieved 22 nov., 2020 from http://www.planalto.gov.br/ccivil_03/leis/1950-1969/14121.htm

GOLDSTEIN, K.(2018). The Open Secret of Anti-Mom Bias at Work. The New York Times, Nova Iorque, 16 mai. Retrieved $26 \mathrm{dec}, 2020$ from https://www.nytimes.com/2018/05/16/opinion/workplacediscriminationmothers.html

IBGE (2017). Síntese de indicadores sociais: uma análise das condições de vida da população brasileira. Coordenação de População e Indicadores Sociais. - Rio de Janeiro:, 2017. Retrieved 05 feb, 2021 from https://biblioteca.ibge.gov.br/visualizacao/livros/liv101459.pdf

IBGE.(2018) Pesquisa Nacional por Amostra de Domicílios Contínua PNAD. Rio de Janeiro, 2018. Retrieved 26 jan, 2021 from https:/www.ibge.gov.br/estatisticas/sociais/trabalho/17270- pnadcontinua.html?ediçã $\mathrm{o}=20636 \& \mathrm{t}=$ sobre

INFOPEN. Produto relatório 5 temático sobre mulheres privadas de liberdade considerando dados do produto 01,02,03,04/ organização Marcos Vinicius Moura Silva. Brasilia: Ministério da Justiça e Segurança Pública, Departamento Penitenciário Nacional.

Lei do Divórcio -Lei $6.515 / 1977 \quad$ Retrieved 06 oct, 2020 from http://www.planalto.gov.br/ccivil_03/leis/16515.htm

LISAUKAS, R.. Ser mãe é padecer na internet. Trabalhar como se não tivesse filhos, ser mãe como se não trabalhasse fora. Retrieved $06 \mathrm{dec}, 2020$ from https:/emais.estadao.com.br/blogs/ser-mae/trabalhar-comose-nao-tivessefilhos-ser-mae-como-se-nao-trabalhasse-fora/

MARTINS, H. (2017). Mães são responsáveis pela criação dos filhos até 3 anos em 89\% dos casos. Agência Brasil. Fortaleza, 7 nov de 2017. Retrieved 08 nov, 2020 from http://agenciabrasil.ebc.com.br/geral/noticia/2017-11/maes-sao-responsaveispela-criacao-dos-filhos-ate-3anos-em-89-dos-casos

QUEIROZ, N. (2015). Presos que Menstruam. Rio de Janeiro Record.

SILVA, A. D. (2015) Mãe/mulher atrás das grades: a realidade imposta pelo cárcere à família monoparental feminina [online]. São Paulo: Editora UNESP; São Paulo: Cultura Acadêmica, 2015, 224 p. ISBN 978-857983-703-6. Retrieved 06 oct, 2020 from https://static.scielo.org/scielobooks/vjtsp/pdf/silva9788579837036.pdf

VENOSA, S. S. (2018) Direito Civil: Direito de Família. 18. ed. - São Paulo : Atlas.

VINHAL,G. (2018) Número de mulheres presas cresce 656\%. Brasil é o quarto país que mais prende. Retrieved $28 \mathrm{dec}, 2020$ from https://medium.com/cartas-do-carcere/n\%C3\%BAmero-de-mulheres-presascresce-656-brasil-\%C3\%A9-o-quarto-pa\%C3\%ADs-que-mais-prende-a06b42c84517 